Z. Klin. Chem. Klin. Biochem.

12. Jg. 1974 , S. $166-170$

\title{
The Effect of Temperature on Enzyme Activity and on the Affinity of Enzymes to their Substrates ${ }^{1}$ )
}

\author{
By G. Szasz
}

Aus dem Institut für Klinische Chemie (Direktor: Prof. Dr. L. Róka) an den Universitätskliniken Gießen

(Eingegangen am 22. Januar 1974)

The effect of temperature on the activity of several diagnostically important enzymes ${ }^{2}$ ) was measured. At $30^{\circ} \mathrm{C}$, the measured activity of some enzymes already differs from that calculated from the Arrhenius plot, while all the enzymes investigated showed a significant deviation of activity at $37^{\circ} \mathrm{C}$. This deviation is independent of the time of pre-incubation (up to 1 hour) and the sample concentration in the assay solution. The activity measured at $25^{\circ} \mathrm{C}$ after a pre-incubation of 1 hour was independent. of the temperature of pre-incubation up to $40^{\circ} \mathrm{C}$. In addition, increased temperature decreased the affinity of $\gamma$-glutamyltransferase and leucine arylamidase for their substrates. The theoretical and practical aspects of the findings are discussed.

Der Einfluß der Temperatur auf die Aktivität mehrerer diagnostisch bedeutsamer Enzyme wurde gemessen. In der Darstellung der Beziehung zwischen Aktivität und Temperatur nach Arrhenius ist eine Krümmung der Kurve für einige Enzyma bereits bei $30^{\circ} \mathrm{C}$ feststellbar und sie wird für alle Enzyme bei $37^{\circ} \mathrm{C}$ deutlich. Die Abweichung von der Geraden ist unabhängig von der Vorinkubationszeit (bis zu einer Stunde) und von der Serumkonzentration im Meßansatz. Die bei $25^{\circ} \mathrm{C}$ gemessene Aktivität nach einer Vorinkubation von einer Stunde ist bis $40^{\circ} \mathrm{C}$ von der Temperatur während der Vorinkubation unabhängig. Zusätzlich wurde eine Abriahme der Affinität der $\gamma$-Glutamyltransferase und der Leucin-Arylamidase zu ihren Substraten bei Erhöhung der Temperatur beobachtet. Die theoretischen und praktischen Aspekte der Ergebnisse werden diskutiert.

The need for the international standardization of enzyme activity measurements is accepted by almost all clinical chemists. According to the Enzyme Commission of the IUB (1) the conditions should be chosen to obtain maximum activity. Since almost all the kinetic factors relevant to the optimization are highly dependent on the assay temperature, the first step in standardisation must be an agreement upon a standard temperature. The discussed alternatives are $25^{\circ} \mathrm{C}, 30^{\circ} \mathrm{C}$ and $37^{\circ} \mathrm{C}(2,3)$. The advantage of higher temperature is the increased sensitivity, which permits either more analyses per time unit or the use of less sample. The extent to which the temperature can be raised is limited by the eventual heatinactivation of the enzymes. The threshold for the onset of thermal inactivation may vary for the individual enzymes, even between isoenzymes and perhaps from sample to sample with different starting activities. It also depends upon the time of incubation.

We know a lot about the stability of the enzyme activity in serum stored at various temperatures, but much less about the behaviour under assay conditions. Most assay solutions are poor in protein and contain unphysiological substances in high concentration such as buffers. We therefore tried to establish the behaviour of some diagnostically important enzymes and isoenzymes under assay conditions at different temperatures and at various times of incubation. In addition the Michaelis constants ${ }^{3}$ ) of some enzyme were estimated at $25^{\circ} \mathrm{C}, 30^{\circ} \mathrm{C}$ and $37^{\circ} \mathrm{C}$ in order to study the . effect of temperature on the affinity of the enzymes to the substrates used.

\section{Materials and Methods Instruments}

Eppendorf photometer with temperature-controlled cuvet holder, linear absorbance converter and recorder ${ }^{4}$ ). Eppendorf micropipets ${ }^{4}$ ) Mikromix, electric stirrer ${ }^{4}$ ).

Haake thermostat FK with built in cooling equipment and thermosistor TP 43 (electronic temperature regulator ${ }^{5}$ ). Tastomed $\mathrm{P}$, electronic temperature measuring instrument ${ }^{6}$ ). Digital pH meter, type $640^{\circ}$ ).

Glass electrode (Einstabmeßkette) Lot $405-\mathrm{M}^{8}{ }^{8}$ ).

\section{Enzymes}

The serum of patients served as the souce of the enzymes. All the sera examined showed a slight to high elevation of activity. The proportion of the sample volume to the total volume of the final reaction mixture was not altered for the same serum over the whole range of temperature. The interpretation of the isoenzyme composition was based on clinical findings and was confirmed electrophoretically for the lactate dehydrogenase.

1) Presented at the 8th International Congress of Clinical Chemistry in Copenhagen (18. - 23.6. 1972) and the 2ème Colloque, Automation et Biologie Prospective in Pont-àMousson (10. - 14. 10. 1972).

2) Enzymes: Aspartate transaminase (EC 2.6.1.1), Alanine tranșaminase (EC 2.6.1.2), Creatinè kinase (EC 2.7.3.2), Lactate dehydrogenase (EC 1.1.7.27), Alkaline phosphatase (EC 3.1.3.1), Leucine arylamidase (EC unknown), $\gamma$-Glutamyltransferase (EC 2.3.2.2).

3) Apparent Michaelis constant.

4) Eppendorf Gerätebau, Netheler-Hinz GmbH, Hamburg

5) Gebrüder Haake, Karlsruhe.

6) Braun Electronic GmbH, Frankfurt/M.

$\left.{ }^{7}\right)$ Knick Elektronische Meßgeräte, Berlin.

${ }^{8}$ ) Dr. W. Ingold KG, Frankfurt/M. 

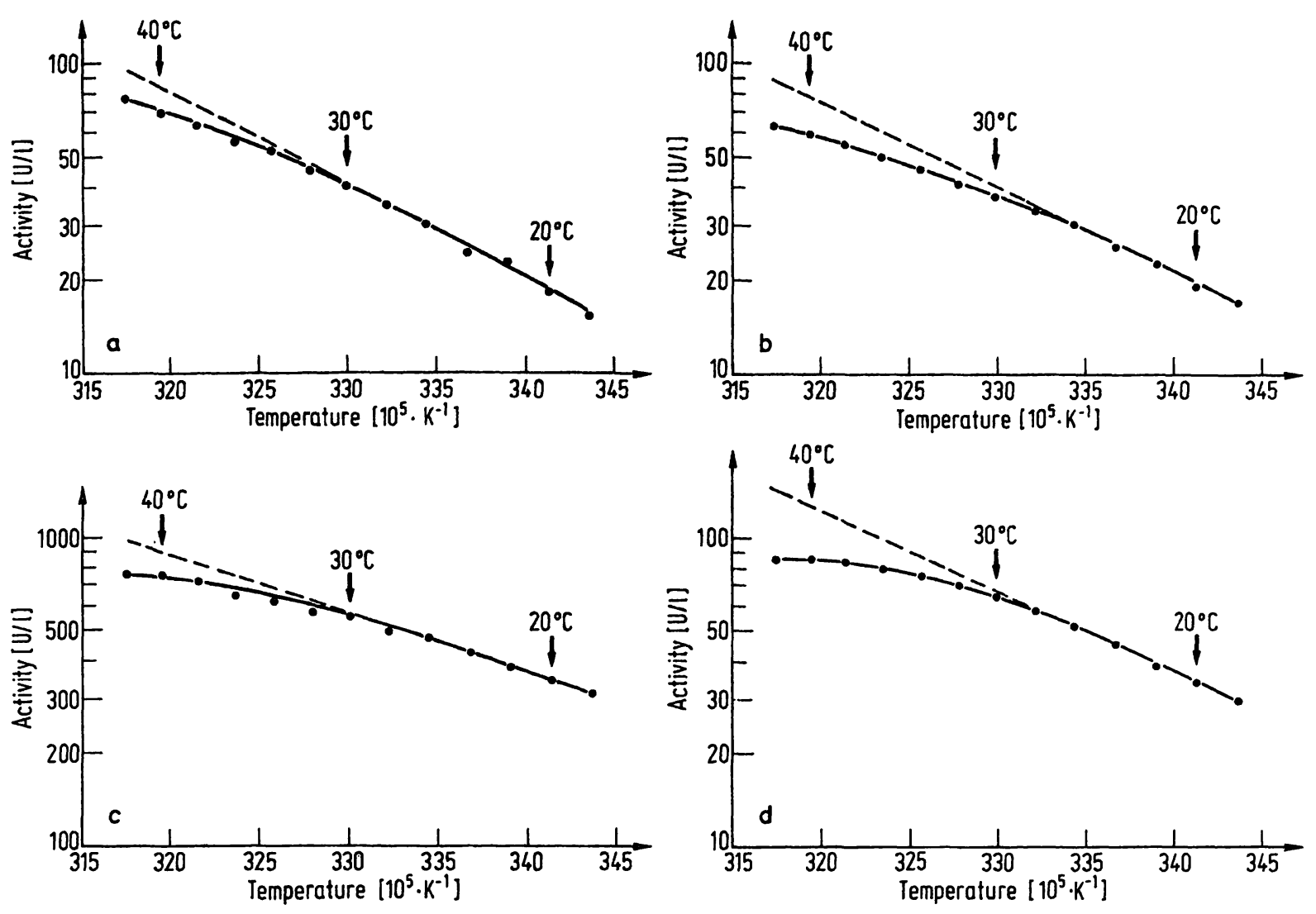

Fig. 1. Effect of temperature on the activity of aspartate aminotransferase (a), alanine aminotransferase (b), alkaline phosphatase (c) and $\gamma$-glutamyltransferase $(d)$

\section{Procedure}

The activities of aspartate transaminase, alanine transaminase, creatine kinase, lactate dehydrogenase, alkaline phosphatase, and leucine arylamidase were measured with the optimized standard methods ${ }^{9}$ ) of the German Society for Clinical Chemistry (4) and the $\gamma$-glutamyltransferase with a method described previously (5) by continuous monitoring of the reaction rate for 2 minutes. Generally a pre-incubation for exactly 5 minutes preceded the activity measurement. The temperature was checked in the cuvets with the electronic temperature measuring instrument several times during the assay and it was constant at a level of \pm 0.1 degree. The $\mathrm{pH}$ was adjusted to allow for the effect of temperature on the $\mathrm{pH}$, then checked again in the thermostated cuvets. To minimize the methodic error, triplicate assays were performed; each plot is the result of investigations in several sera on different days.

\section{Results}

\section{Arrhenius plot}

The activity of severai enzymes, measured between 18 and 42 degrees at two degree intervals, was plotted against the temperature according to Arrhenius (Fig. 1, 2 and 3). The deviation of the measured activity from the activity calculated from the Arrhenius plot is given in table 1 . At $25^{\circ} \mathrm{C}$ the measured and calculated $\mathrm{T}$ activity was the same for all enzymes and isoenzymes. At $30^{\circ} \mathrm{C}$, this was still true for aspartate aminotransferase, alkaline phosphatase and the fast moving fractions of lactate dehydrogenase, but alanine aminotransferase, creatine kinase, $\boldsymbol{\gamma}$-glutamyltransferase and the slow moving fractions of lactate dehydrogenase already showed a difference of between 2 and 9 percent. The deviation at $37^{\circ} \mathrm{C}$ is highly significant for every enzyme and lies between 12 and 27 percent.

There was no significant difference between the aspartate aminotransferase in the sera of patients with myocardial infarction and those with liver disease; creatine kinase was the same in the sera of patients with myocardial infarction or skeletal muscle damage (Fig. 2); and alkaline phosphatase was the same in the sera of patients with obstructive jaundice or bone disease. In spite of this the deviation of the measured activity of the slow moving lactate dehydrogenase (electrophoretically $50 \% \mathrm{LDH}_{5}$ ) from the activity calculated from the Arrhenius plot was more than twice as high as for the fast moving lactate dehydrogenase (predominantly $\mathrm{LDH}_{1}$ and $\mathrm{LDH}_{2}$ ) (Fig. 3 and tab. 1).

\section{The effect of incubation time on activity}

The dependence of the activity on the time of incubation was studied for alanine aminotransferase and $\boldsymbol{\gamma}$-glutamyltransferase. Sera were pre-incubated in the assay solution for an hour at $20^{\circ} \mathrm{C}, 25^{\circ} \mathrm{C}, 30^{\circ} \mathrm{C}$, $35^{\circ} \mathrm{C}$, and $40^{\circ} \mathrm{C}$. The reactions were then started by the addition of 2-oxoglutarate and $L$ - $\gamma$-glu tamyl-pnitroanilide, respectively. The activities measured 
Tab. 1. Deviation between the activities measured and calculated from the Arrhenius plots

\begin{tabular}{|c|c|c|c|c|c|c|c|}
\hline & $\begin{array}{l}\text { Aspartate } \\
\text { amino- } \\
\text { transferase }\end{array}$ & $\begin{array}{l}\text { Alanine } \\
\text { amino- } \\
\text { transferase }\end{array}$ & $\begin{array}{l}\text { Creatine } \\
\text { kinase }\end{array}$ & $\begin{array}{l}\text { Alkaline } \\
\text { phosphatase }\end{array}$ & $\begin{array}{l}\text { rGlutamyl- } \\
\text { transferase }\end{array}$ & $\begin{array}{l}\text { Lactate } \\
\text { dehydrogenase } \\
\text { "fast" }\end{array}$ & $\begin{array}{l}\text { Lactate } \\
\text { dehydrogenase } \\
\text { "slow" }\end{array}$ \\
\hline \multicolumn{8}{|c|}{ (percent) } \\
\hline $\begin{array}{l}30^{\circ} \mathrm{C} \\
37^{\circ} \mathrm{C}\end{array}$ & $\begin{array}{r}0 \\
15\end{array}$ & $\begin{array}{r}5 \\
17\end{array}$ & $\begin{array}{r}2 \\
22\end{array}$ & $\begin{array}{r}0 \\
12\end{array}$ & $\begin{array}{r}5 \\
23\end{array}$ & $\begin{array}{r}0 \\
13\end{array}$ & $\begin{array}{r}9 \\
27 .\end{array}$ \\
\hline
\end{tabular}

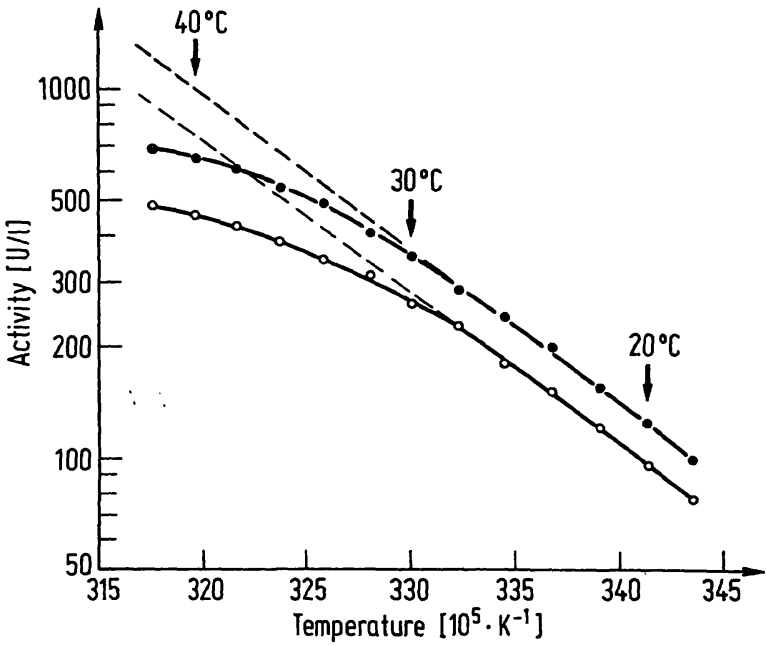

Fig. 2. Effect of temperature on the activity of creatine kinase

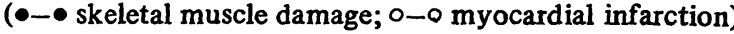
plotted according to Arrhenius.

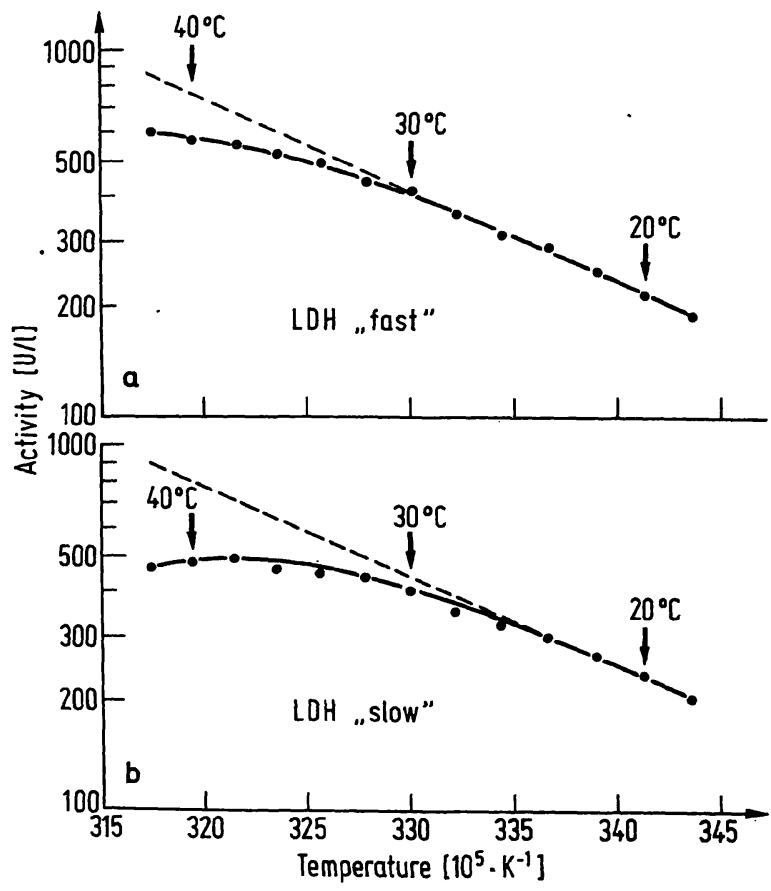

Fig. 3. Effect of temperature on the activity of the lactate dehy drogenase (a "fast"; $b$ "slow") isoenzymes plotted according to Arrhenius. after a pre-incubation of one hour or 2 minutes did not differ significantly, even when the pre-incubation temperature was $40^{\circ} \mathrm{C}$ (Tab. 2).

In another series ( $\mathrm{Tab} .3$ ), sera were preincubated for an hour under the same conditions as above; they were then cooled to $25^{\circ} \mathrm{C}$ and the reaction was started with the corresponding substrate. The activity measured at $25^{\circ} \mathrm{C}$ was independent of the temperature of the pre-incubation.

Tab. 2. Influence of pre-incubation at different temperatures on the activity $(\mathrm{U} / \mathrm{l})$

\begin{tabular}{lccccccc}
\hline & \multicolumn{6}{c}{ Temperature of pre-incubation } \\
& $\begin{array}{l}\text { Pre- } \\
\text { incu- } \\
\text { bation }\end{array}$ & $20^{\circ} \mathrm{C}$ & $25^{\circ} \mathrm{C}$ & $30^{\circ} \mathrm{C}$ & $35^{\circ} \mathrm{C}$ & $40^{\circ} \mathrm{C}$ \\
\hline $\begin{array}{l}\text { Alanine } \\
\text { aminotransferase }\end{array}$ & $2 \mathrm{~min}^{+}$ & 16.8 & 20.2 & 26.6 & 32.4 & 43.5 \\
$\gamma$-Glutamyl- & 16.3 & 19.2 & 24.4 & 31.2 & 42.0 \\
transferase & $60 \mathrm{~min}^{++}$ & 38.2 & 54.4 & 69.6 & 86.8 & 98.2 \\
\hline
\end{tabular}

+ After adding NADH and lactate dehydrogenase, incubation was continued for a further $5 \mathrm{~min}$, and the reaction was started with 2-oxoglutarate.

++ Started by the addition of $L-\gamma$-glutamyl-p-nitroanilide

Tab. 3. Influence of pre-incubation for an hour at different temperatures on the activity $(\mathrm{U} / 1)$ measured at $25^{\circ} \mathrm{C}$.

\begin{tabular}{lccccccc} 
& \multicolumn{6}{c}{ Temperature of the pre-incubation } \\
& & $20^{\circ}$ & $25^{\circ}$ & $30^{\circ}$ & $35^{\circ}$ & $40^{\circ}$ \\
\hline Alanine $_{\text {aminotransferase }}{ }^{+}$ & Serum 1 & 34.4 & 32.6 & 32.6 & 34.4 & 34.4 \\
& Serum 2 & 60.0 & 60.0 & 57.6 & 58.8 & 58.8 \\
& Serum 3 & 104 & 104 & 100 & 100 & 100 \\
r-Glutamyl- & & & & & & \\
transferase & Serum 1 & 80.8 & 80.8 & 80.8 & 77.8 & 80.8 \\
& Serum 2 & 119 & 119 & 119 & 121 & 123 \\
& Serum 3 & 275 & 275 & 275 & 275 & 275 \\
\hline
\end{tabular}

+ Pre-incubation for an hour, followed bý a further 5 min at $25^{\circ} \mathrm{C}$ after adding NADH and lactate dehydrogenase, then started with 2-oxoglutarate.

${ }^{++}$Started by the addition of $L-\gamma$-glutamyl-p-nitroanilide. 
Effect of sample concentration in the assay solution

Sera with high $\mathrm{LDH}_{5}$ and $\boldsymbol{\gamma}$-glutamyltransferase activities were diluted 1:20 with physiological sodium chloride solution and with human albumin or inactivated serum, respectively. The activity measured at $20^{\circ} \mathrm{C}, 25^{\circ} \mathrm{C}, 30^{\circ} \mathrm{C}, 35^{\circ} \mathrm{C}$, and $40^{\circ} \mathrm{C}$ was independent of the diluent used (Tab. 4).

\section{Effect of temperature on the Michaelis constant ${ }^{3}$ )}

The Michaelis constants of $\boldsymbol{\gamma}$-glutamyltransferase and leucine arylamidase for $L$ - $\gamma$-glutamyl-p-nitroanilide and $L$-leucyl- $p$-nitroanilide, respectively were estimated at $25^{\circ} \mathrm{C}, 30^{\circ} \mathrm{C}$ and $37^{\circ} \mathrm{C}$. The $\mathrm{K}_{\mathrm{m}}$ values of both enzymes increase gradually with the temperature; consequently the affinity of the enzymes to their substrates decreases (Fig. 4 and 5).

\section{Discussion}

According to our observations, the measured enzyme activity at higher temperatures differs from that calculated from the Arrhenius plot. For several enzymes, a deviation is observed as low as $30^{\circ} \mathrm{C}$ (up to $9 \%$ ) and this becomes significant (up to $27 \%$ ) at $37^{\circ} \mathrm{C}$ for all

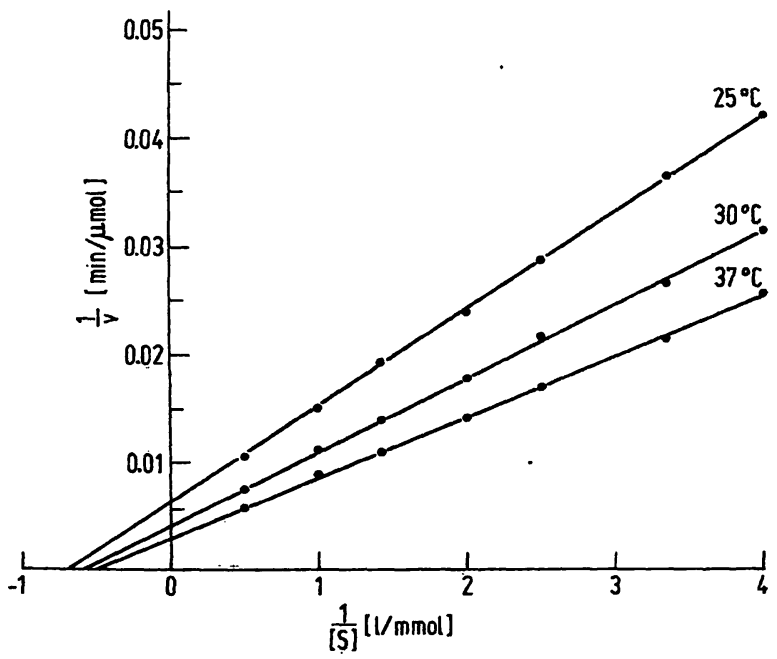

Fig. 4. Michaelis constant of $\gamma$-glutamyltransferase for $L-\gamma$-glutamyl-p-nitroanilide at various temperatures - LineweaverBurk plot: $\mathrm{K}_{\mathrm{m}}=1.47\left(25^{\circ} \mathrm{C}\right), 1.67\left(30^{\circ} \mathrm{C}\right), 2.60\left(37^{\circ} \mathrm{C}\right)$ $\mathrm{mmol} / \mathrm{l}$

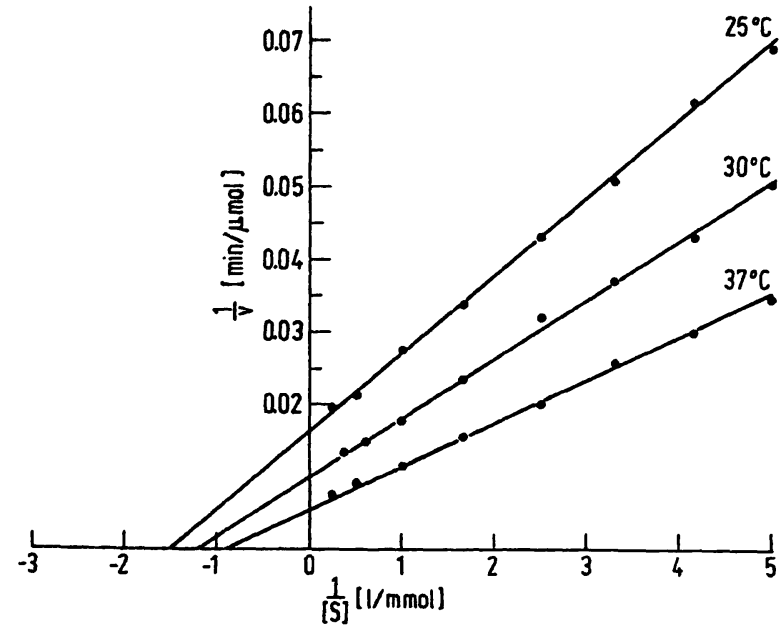

Fig. 5. Michaelis constant of leucine arylamidase for $L$-leucinep-nitroanilide at various temperatures - Lineweaver-Burk plot: $\mathrm{K}_{\mathrm{m}}=0.66\left(25^{\circ} \mathrm{C}\right), 0.81\left(30^{\circ} \mathrm{C}\right), 1.05\left(37^{\circ} \mathrm{C}\right) \mathrm{mmol} / \mathrm{l}$

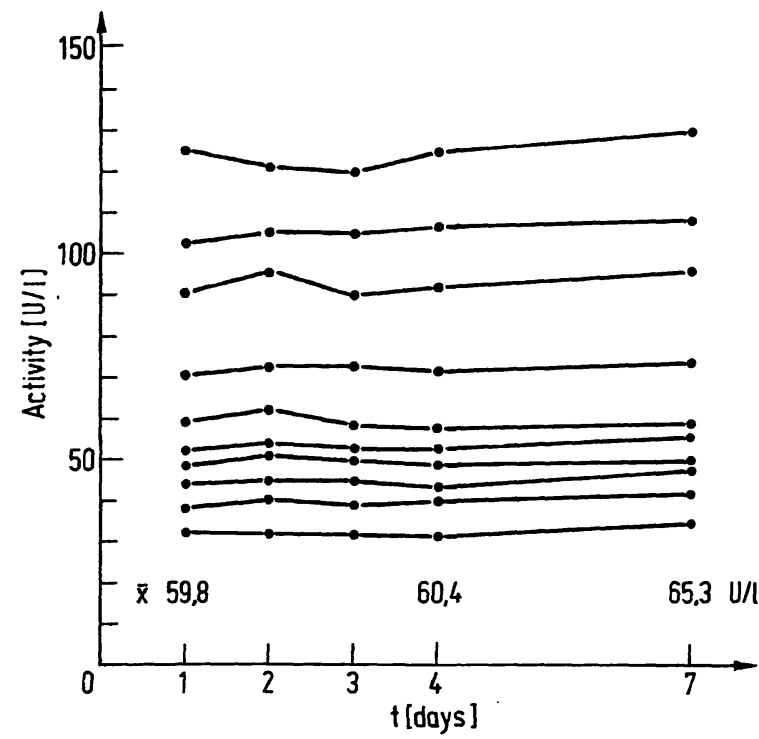

Fig. 6. Stability of $\gamma$-glutamyltransferase stored at $37^{\circ} \mathrm{C}$.

the enzymes studied. It is not only those enzymes known to be temperature-sensitive that deviate from the Arrhenius plot; the same behaviour is shown by very stable enzymes, such as $\boldsymbol{\gamma}$-glutamyltransferase (Fig. 6). Several explanations are possible for the

Tab. 4. Influence of sample concentration in the assay solution on the activity (U/l)

\begin{tabular}{lllcccc}
\hline \multicolumn{5}{c}{ Assay temperature } \\
\hline & $1: 20$ diluted with & $20^{\circ} \mathrm{C}$ & $25^{\circ} \mathrm{C}$ & $30^{\circ} \mathrm{C}$ & $35^{\circ} \mathrm{C}$ & $40^{\circ} \mathrm{C}$ \\
\hline Lactate dehydrogenase & Human albumin & 161 & 206 & 245 & 287 & 255 \\
"slow" & $\mathrm{NaCl}, 0.9 \%$ & 157 & 195 & 235 & 261 & 245 \\
rGlutamyltransferase & inact. serum & 42.8 & 66.8 & 75.0 & 88.4 & 100 \\
& $\mathrm{NaCl}, 0.9 \%$ & 40.4 & 64.2 & 73.0 & 86.8 & 96.6 \\
\hline
\end{tabular}


deviation from the straight line in the Arrhenius plot at higher temperature:

1. The enzyme protein alters its structure with increasing temperature. The alteration is immediate and reversible for the enzymes investigated up to $40^{\circ} \mathrm{C}$, and it is independent of the sample concentration in the assay solution. The structure of the enzyme protein thereby becomes unfavourable for the reaction catalyzed.

2. The optimal conditions for enzyme activity depend on the temperature. Ellis and Goldbarg (6) found temperature-dependent $\mathrm{pH}$ optima and $\mathrm{K}_{\mathrm{m}}$ values for lactate dehydrogenase using 2-oxobutyrate as substrate. A decrease in the affinity of $\gamma$-glutamyltransferase and leucine arylamidase to their substrates with increasing temperature was observed by us in this study. It is possible that the deviation from the straight line in the Arrhenius plot would disappear if the conditions were optimized for the different temperatures used. In my opinion both explanations might have a common basis. Enzymes react according to the simplified stoichiometric equations:

$\mathrm{E}+\mathrm{S} \underset{\mathrm{k}_{1}}{\stackrel{\mathrm{k}_{+1}}{\rightleftharpoons}} \mathrm{ES} \underset{\mathrm{k}_{-2}}{\stackrel{\mathrm{k}_{+2}}{\rightleftharpoons}} \mathrm{E}+\mathrm{P}$

where: $E$ = free enzyme, $S=$ substrate, $E S=$ enzyme substrate complex, $\mathrm{P}=$ reaction product and $\mathrm{k}=$ rate constant.

\section{References}

1. Report of the Commission on Enzymes of the International Union of Biochemistry (1961), Pergamon, Oxford.

2. King, J. (1972), Ann. Clin. Biochem. 9, 197-202.

3. Bergmeyer, H. U. (1973), this J. 11, 39-4.5.
The reaction velocity is generally limited by $k_{+2}$; at the beginning of the reaction the concentration of the product is almost nought and the enzyme is saturated with substrate $\left(\mathbf{k}_{+1} \gg \mathbf{k}_{-1}\right)$, if an optimized method is used, and $\mathrm{k}_{-2}$ therefore tends to 0 . An increase in temperature will therefore cause a higher reaction rate, if the rate of splitting of $E S$ to $E$ and $P$ $\left(k_{+2}\right)$ is raised. Apparently the speed of the competing direction of the reaction $\left(k_{-1}\right)$ also increases, so that one needs a higher substrate concentration for the saturation of the enzyme. This fact can be explained by an unfavourable structure of the enzyme protein for the reaction catalyzed at a higher temperature. But an unfavourable structure of an enzyme at higher temperature is simply another way of saying that the enzyme has suffered a partial thermal inactivation.

The practical aspects of this study are: the reaction rate is obviously constant even at $37^{\circ} \mathrm{C}$ for at least several minutes. Methods optimized for $25^{\circ} \mathrm{C} \mathrm{(4)} \mathrm{are}$ at $37^{\circ} \mathrm{C}$ mostly suboptimal. Since the optimal substrate concentration at $25^{\circ} \mathrm{C}$ is already, at least for $\gamma$-glutamyltransferase and leucine arylamidase, close to the limit of solubility, it will hardly be possible to work at optimal conditions at $37^{\circ} \mathrm{C}$. Temperature conversion factors are not acceptable to convert individual results from $37^{\circ} \mathrm{C}$ to $25^{\circ} \mathrm{C}$, or vice versa, since isoenzymes may be differently influenced by temperature.
4. Recommendations of the German Society for Clinical Chemistry (1972), this J. 10, 281-291.

5. Szasz, G. (1969), Clin. Chem. 15, 124-136

6. Ellis, G. \& Goldbarg, D. M. (1971), Amer. J. Clin. Pathol. $56,627-635$. 